\title{
Isolation of flavonol rhamnosides from Pometia pinnata leaves and investigation of $\alpha$-glucosidase inhibitory activity of flavonol derivatives
}

Fadhila Utari ${ }^{1}$, Afrizal Itam ${ }^{1}$, Syafrizayanti Syafrizayanti ${ }^{1}$, Widya Hasvini Putri ${ }^{1}$, Masayuki Ninomiya ${ }^{2}$, Mamoru Koketsu ${ }^{2}$, Kaori Tanaka ${ }^{3}$, Mai Efdi ${ }^{*}$

${ }^{1}$ Department of Chemistry, Faculty of Mathematics and Natural Science, Andalas University, Padang, Indonesia. ${ }^{2}$ Department of Chemistry and Biomolecular Science, Faculty of Engineering, Gifu University, Gifu, Japan.

${ }^{3}$ Division of Anaerobe Research, Life Science Research Centre, Gifu University, Gifu, Japan.

\begin{tabular}{l}
\hline ARTICLE INFO \\
\hline Received on: 02/03/2019 \\
Accepted on: 26/05/2019 \\
Available online: 03/08/2019
\end{tabular}

\section{Key words:}

Pometia pinnata, $\alpha$-glucosidase inhibitory, kaempferol-3-O-rhamnoside, quercetin-3-O-rhamnoside, UPLC-ESI-TOFMS.

\begin{abstract}
Pometia pinnata belonging to the Sapindaceae family has been traditionally used as the therapeutic agent for burns and wounds in Indonesia. Based on the result of the experiment conducted, the ethyl acetate fraction of $P$. pinnata leaves showed strong $\alpha$-glucosidase inhibitory activity. After two flavonol rhamnoside compounds were isolated from ethyl acetate fraction of $P$. pinnata leaves methanol extract using chromatography method, their structures were identified as kaempferol-3-O-rhamnoside (1) and quercetin-3-O-rhamnoside (2). The ultra-performance liquid chromatographyelectrospray ionization time-of-flight mass spectrometry (UPLC-ESI-TOFMS) chromatogram showed compounds 1 and $\mathbf{2}$ were the major compounds of the ethyl acetate fraction. In this study, the structure-activity relationship among the kaempferol, quercetin, and their derivatives bearing sugar moiety were also evaluated. Among tested eight compounds, kaempferol 7 (percent inhibition $=80.10 \% \pm 0.8$ ) and quercetin 8 (percent inhibition $=82.93 \% \pm 0.4$ ) had stronger $\alpha$-glucosidase inhibitory activity than that of other derivatives. Among kaempferol derivatives bearing sugar moiety, compound $\mathbf{1}$ showed the strongest activity. Moreover, compound $\mathbf{2}$ showed strong $\alpha$-glucosidase inhibitory activity among quercetin derivatives. Therefore, it can be confirmed that the hydroxyl group at C-3 position is very important for $\alpha$-glucosidase inhibitory activity of flavonol compounds.
\end{abstract}

\section{INTRODUCTION}

Pometia genus belongs to the Sapindaceae family. This genus comprises 10 species that are distpersed from Malaysia to India (Jayasinghe et al., 2000). Pometia pinnata is one of the interesting species among Pometia genus. This plant has been traditionally used as a therapeutic agent for burns and wounds in Indonesia (Lense, 2012). Previously, the biological activities of $P$. pinnata extracts were reported. The methanol extract of the bark revealed antioxidant and antifungal activities (Kawamura et al., 2010). The ethanol extract

"Corresponding Author

Mai Efdi, Department of Chemistry, Faculty of Mathematics and Natural

Science, Andalas University, Padang, Indonesia.

E-mail:maiefdi@sci.unand.ac.id of the bark also was reported to have $\alpha$-glucosidase and $\alpha$-amylase inhibitory activities (Elya et al., 2015). Recently, the tyrosinase inhibitory activities from the ethanol extract of the bark and leaves were studied (Sauriasari et al., 2017). Furthermore, the ethanol extract of the leaves and proanthocyanidin A2 from $P$. pinnata leaves indicated strong anti-HIV activity (Suedee et al., 2013). Nevertheless, there are no reported flavonol glycosides isolated from $P$. pinnata leaves as $\alpha$-glucosidase inhibition. The aims of this research are to isolate secondary metabolites of $P$. pinnata leaves and to evaluate the $\alpha$-glucosidase inhibitory activity of flavonol derivatives.

\section{MATERIAL AND METHODS}

\section{General}

All solvents and reagents were purchased from Wako Pure Chemical Industries, Ltd (Osaka, Japan) and used without 
further purification. Silica gel for column chromatography (CC) was performed on silica gel N60 (Wakogel 60N, 38-100 $\mu \mathrm{m}$ ) and TLC plates pre-coated with silica gel $70 \mathrm{~F}_{254}(60-200$ mesh Wako gel) were purchased from Wako Pure Chemical Industries, Ltd (Osaka, Japan). The separation spots of CC were monitored under the UV lamp (254 and $365 \mathrm{~nm}$ ) and also by spraying with $10 \% \mathrm{CeSO}_{4}$ followed by heating. IR spectra were measured on a PerkinElmer FT-IR/FIR Spectrometer $400 .{ }^{1} \mathrm{H},{ }^{13} \mathrm{C}$, heteronuclear multiple-quantum correlation (HMQC), heteronuclear multiple bond correlation (HMBC), and ${ }^{1} \mathrm{H}-{ }^{1} \mathrm{H}$-correlation spectroscopy $\left({ }^{1} \mathrm{H}-{ }^{1} \mathrm{H}-\mathrm{COSY}\right)$ nuclear magnetic resonance (NMR) spectra were recorded with JEOL JNM-ECS 400 spectrometer using tetramethylsilane (TMS) as an internal standard. MS spectra were recorded using the Waters UPLC-ESI-TOFMS system (Aquity UPLC XevoQTof) (Waters Corporation, Milford).

\section{Plant material}

The fresh leaves of $P$. pinnata $(12 \mathrm{~kg})$ were collected from the environment of Limau Manis, Padang, West Sumatera, Indonesia in June 2017 and later identified at Herbarium of Universitas Andalas, Padang, West Sumatera, Indonesia.

\section{Extraction and isolation of secondary metabolites}

The dried leaves $(4 \mathrm{~kg})$ were extracted using $\mathrm{MeOH}$ (12 L) at room temperature for 3 days, after that filtered and evaporated under vacuum. Afterward, the crude $\mathrm{MeOH}$ extract was partitioned subsequently to yield $n$-hexane fraction $(45.5 \mathrm{~g})$, dichloromethane (DCM) fraction (25.4 g), and EtOAc fraction (48.7 g), respectively.

EtOAc fraction of P. pinnata leaves $(40.0 \mathrm{~g})$ was separated by $\mathrm{SiO}_{2} \mathrm{CC}$ eluting with mixtures of $n$-hexane/EtOAc (100:0-0:100 $\mathrm{v} / \mathrm{v})$, EtOAc/MeOH (100:0-0:100 v/v) to obtain 15 fractions (Fr. A to Fr. O). Fraction D (14.1 g) was performed on silica gel CC using a mixture of $n$-hexane/EtOAc $(9: 1 \mathrm{v} / \mathrm{v})$ to yield five sub-fractions (D1-D5). Fraction D4 (1.1 g) was separated by CC using EtOAc to give three sub-fractions (D4.1-D4.3). Fraction D4.1 (361.2 mg) was purified by recrystallization to obtain compound $\mathbf{1}(211.7 \mathrm{mg})$. Fraction D4.2 (188.9 mg) was purified by $\mathrm{CC}$ using $\mathrm{CHCl}_{3} / \mathrm{MeOH}$ $(5: 1 \mathrm{v} / \mathrm{v})$ to yield compounds $2(17.4 \mathrm{mg})$ and also $\mathbf{1}(39.0 \mathrm{mg})$.

\section{Identification of secondary metabolites}

According to the analysis of spectroscopic data, including IR, NMR (1D, 2D), and MS, the structures of compounds (1-2) were determined. The NMR spectroscopic data were recorded at $400 \mathrm{MHz}$ for ${ }^{1} \mathrm{H}$ and $100 \mathrm{MHz}$ for ${ }^{13} \mathrm{C}$ using TMS as an internal standard.

\section{Kaempferol-3-O-rhamnoside (1)}

Yellow amorphous powder. IR ${ }_{V \max } 3253,2956,1651$, 1361, 1171, and $828 \mathrm{~cm}^{-1} .{ }^{1} \mathrm{H}$ NMR (400 MHz, $\left(\mathrm{CD}_{3}\right)_{2} \mathrm{CO}(\mathrm{ppm})$ : $\delta 7.84\left(2 \mathrm{H}, \mathrm{dd}, J=8.7,2.8 \mathrm{~Hz}, \mathrm{H}-2^{\prime}\right.$ and $\left.\mathrm{H}-6^{\prime}\right), 7.01(2 \mathrm{H}, \mathrm{dd}, J=$ $8.7,2.8 \mathrm{~Hz}, \mathrm{H}-3^{\prime}$ and $\left.\mathrm{H}-5^{\prime}\right), 6.45(1 \mathrm{H}, \mathrm{d}, J=2.3 \mathrm{~Hz}, \mathrm{H}-8), 6.25$ $(1 \mathrm{H}, \mathrm{d}, J=1.8 \mathrm{~Hz}, \mathrm{H}-6), 5.52\left(1 \mathrm{H}, \mathrm{d}, J=1.4 \mathrm{~Hz}, \mathrm{H}-1^{\prime \prime}\right), 4.20(1 \mathrm{H}$, d, $\left.J=1.4 \mathrm{~Hz}, \mathrm{H}-2^{\prime \prime}\right), 3.70\left(1 \mathrm{H}, \mathrm{dd}, J=3.7,8.7 \mathrm{~Hz}, \mathrm{H}-3^{\prime \prime}\right), 3.30$ $\left(2 \mathrm{H}, \mathrm{m}, \mathrm{H}-4\right.$ " and $\left.\mathrm{H}-5^{\prime \prime}\right)$, and $0.90\left(3 \mathrm{H}, \mathrm{d}, J=6.0 \mathrm{~Hz}, \mathrm{Me}-6{ }^{\prime \prime}\right) .{ }^{13} \mathrm{C}$ NMR (100 MHz, $\left.\left(C D_{3}\right){ }_{2} C O, p p m\right): \delta 178.4$ (C-4), 164.3 (C-7), 162.3 (C-5), 160.1 (C-9), 157.7 (C-4'), 157.1 (C-2), 134.9 (C-3), $130.9\left(\mathrm{C}-2^{\prime}\right.$ and ${\mathrm{C}-6^{\prime}}^{\prime}), 121.6\left(\mathrm{C}-1^{\prime}\right), 115.5\left(\mathrm{C}-3^{\prime}\right.$ and $\left.\mathrm{C}-5^{\prime}\right), 104.9$ (C-10), 101.9 (C-1"), 98.8 (C-6), 93.8 (C-8), 72.0 (C-4"), 71.0 (C$\left.2^{\prime \prime}\right), 70.7$ (C-3"), 70.6 (C-5"), 17.0 (Me-6"). HRESITOFMS: $m / z$ $455.0944[\mathrm{M}+\mathrm{Na}]^{+}$(calcd. for $\mathrm{C}_{21} \mathrm{H}_{20} \mathrm{O}_{10} \mathrm{Na}, 455.0954$; error: 2.2 ppm).

\section{Quercetin-3-O-rhamnoside (2)}

Yellow amorphous powder. IR $V_{\max } 3198,2923,1652$, 1354, 1195, $808 \mathrm{~cm}^{-1} .{ }^{1} \mathrm{H}$ NMR (400 MHz, $\left.C D_{3} O D, \mathrm{ppm}\right): \delta 7.33$ $\left(1 \mathrm{H}, \mathrm{d}, J=1.9 \mathrm{~Hz}, \mathrm{H}-2^{\prime}\right), 7.30\left(1 \mathrm{H}, \mathrm{dd}, J=8.2,2.3 \mathrm{~Hz}, \mathrm{H}-6^{\prime}\right), 6.91$ $\left(1 \mathrm{H}, \mathrm{d}, J=8.2 \mathrm{~Hz}, \mathrm{H}-5^{\prime}\right), 6.36(1 \mathrm{H}, \mathrm{d}, J=1.8 \mathrm{~Hz}, \mathrm{H}-8), 6.20(1 \mathrm{H}$, $\mathrm{d}, J=1.8 \mathrm{~Hz}, \mathrm{H}-6), 5.30$ (1H, d, $\left.J=1.4 \mathrm{~Hz}, \mathrm{H}-1^{\prime \prime}\right), 4.20$ (1H, dd, $J$ $\left.=3.2,1.4 \mathrm{~Hz}, \mathrm{H}-2^{\prime \prime}\right), 3.70(1 \mathrm{H}, \mathrm{dd}, J=9.1,3.7 \mathrm{~Hz}, \mathrm{H}-3 "), 3.40(1 \mathrm{H}$, dd, $\left.J=5.9,9.6 \mathrm{~Hz}, \mathrm{H}-5^{\prime \prime}\right), 3.30$ (1H, dd, $\left.J=5.9,9.6 \mathrm{~Hz}, \mathrm{H}-4^{\prime \prime}\right)$, $0.90(3 \mathrm{H}, \mathrm{d}, J=6.0 \mathrm{~Hz}, \mathrm{Me}-6 ") .{ }^{13} \mathrm{C} \mathrm{NMR}\left(100 \mathrm{MHz}, C D_{3} O D\right.$, ppm): $\delta 178.3$ (C-4), 164.6 (C-7), 161.9 (C-5), 158.0 (C-9), 157.2 (C-2), 148,5 (C-4'), 145.1 (C-3'), 134.9 (C-3), 121.6 (C-1'), 121.5 (C-6'), 115.6 (C-5'), 115.0 (C-2'), 104.6 (C-10), 102.2 (C-1"), 98.4 (C-6), 93.4 (C-8), 71.9 (C-4"), 70.8 (C-2"), 70.7 (C-3"), 70.6 (C5"), 16.3 (Me-6") HRESITOFMS: $m / z 471.0886[\mathrm{M}+\mathrm{Na}]^{+}$(calcd. for $\mathrm{C}_{21} \mathrm{H}_{20} \mathrm{O}_{11} \mathrm{Na}$, 471.0903; error: $3.7 \mathrm{ppm}$ ).

\section{Determination of $\alpha$-glucosidase inhibitory activity}

Chemical reagents

$\alpha$-Glucosidase [(EC 3.2.1.20)] from Saccharomyces cerevisiae, $\quad p$-nitrophenyl $\alpha$-D-glucopyranoside $\quad(p \mathrm{NPG})$ and quercetin (8) were purchased from Sigma-Aldrich, Co. Dimethyl sulfoxide (DMSO) was purchased from Wako Pure Chemical Industries, Ltd (Japan). Three compounds, astragalin (3), isoquercetin (4), and nicotiflorin (5) were isolated from Eleutherococcus sieboldianus leaves (Nishina et al., 2017). Rutin (6) and kaempferol (7) were purchased from Tokyo Chemical Industry, Ltd (Tokyo, Japan). A 96-well microtiter plate was purchased from Corning Inc. (Corning Costar, Cambridge, MA).

\section{$\alpha$-Glucosidase inhibitory assay}

$\alpha$-Glucosidase inhibitory activity was evaluated according to the previous method(Dewi et al., 2015). $\alpha$-Glucosidase (50 $\mu \mathrm{l}, 0.5 \sim$ Unit $/ \mathrm{mg}$ ) and $2 \mu \mathrm{l}$ of various concentrations of the sample in DMSO were poured into 96-well microplate, and then pre-incubated at $37^{\circ} \mathrm{C}$ for 5 minutes. The reaction was started by the addition of $50 \mu \mathrm{l}$ of $p$ NPG $(5 \mathrm{mM})$. The mixture was later incubated at $37^{\circ} \mathrm{C}$ for 5 minutes. The $\alpha$-glucosidase activity was measured by using a microplate reader $\left(E_{\max }\right.$ precision microplate reader, Molecular Devices Japan, Tokyo, Japan) at $405 \mathrm{~nm}$. The $\%$ inhibition value expressed $\alpha$-glucosidase inhibitory activity of each sample and calculated as follows (Eq. 1):

$\%$ Inhibition $=100-\left(\frac{\text { Abs control }- \text { Abs sample }}{\text { Abs control }} \times 100\right)$

where the control represents the assay in which the sample is replaced by the solvent used in its preparation.

\section{UPLC-ESI-TOFMS analysis}

The EtOAc fraction of $P$. pinnata leaves was dissolved in $\mathrm{DMSO} / \mathrm{H}_{2} \mathrm{O}(1 / 1)$ at $20 \mathrm{mg} / \mathrm{ml}$ and filtered across $0.45 \mu \mathrm{m}$ membrane filter (ADVANTEC ${ }^{\circledR}$, Japan). An aliquot $(5 \mu \mathrm{l})$ of the sample was injected in the Waters UPLC system (Aquity UPLC XevoQTof). Analysis was carried out by UPLC system using a UPLC BEH $\mathrm{C}_{18}$ analytical column $(1.7 \mu \mathrm{m}, \varnothing 2.1 \times 100 \mathrm{~mm})$. The mobile phase contained solvent A (distilled water) and solvent $\mathrm{B}$ $(\mathrm{MeOH})$. The condition of linear gradient system: 0-30 minutes ( $90 \%$ to $70 \%$ solvent $\mathrm{A}$ and $10 \%$ to $30 \%$ solvent B); was kept for $5 \mathrm{~min}$; $35-45$ minutes $(70 \%$ to $50 \%$ solvent $A$ and $30 \%$ to 
$50 \%$ solvent B). The column eluate was monitored at $260 \mathrm{~nm} \mathrm{UV}$ absorbance. The negative mode was employed in ESI-TOFMS (Pardede and Koketsu, 2017).

\section{RESULTS AND DISCUSSION}

$\alpha$-Glucosidase inhibitory activity of Pometia pinnata fractions

Fractions of $n$-hexane (45.5 g), DCM (25.4 g), and EtOAc (48.7 g) were obtained by successively fractionation of $\mathrm{MeOH}$ extract of $P$. pinnata leaves. As preliminary screening, we evaluated in vitro inhibitory activity of three fractions of $P$. pinnata leaves against $\alpha$-glucosidase of $S$. cerevisiae with slight modification (Dewi et. al., 2015). In this study, the EtOAc fraction of $P$. pinnata leaves showed the strongest inhibitory activity against $\alpha$-glucosidase (percent inhibition $=95.5 \% \pm 0.7$ ) at 100 $\mu \mathrm{g} / \mathrm{ml}$. DCM fraction had inhibitory activity (percent inhibition $=$ $84.7 \% \pm 0.1)$ at the same concentration, while $n$-hexane fraction showed poor inhibitory activity (percent inhibition $=38.7 \% \pm 1.9$ ) (Fig. 1). According to this result, the compounds from EtOAc fraction of $P$. pinnata leaves must be isolated.

\section{Characterization of isolated compounds}

To ascertain the potential compounds with respect to these properties, the EtOAc fraction of $P$. pinnata leaves was separated by $\mathrm{CC}$ on silica gel $\left(\mathrm{SiO}_{2}\right)$ and later purified by $\mathrm{CC}$ and recrystallization to obtain two flavonol rhamnoside compounds, namely, compound 1 (146.5 $\mathrm{mg}$ ) and compound 2 (17.4 mg). The chemical structure of isolated compounds was elucidated based on spectroscopic data, including IR, ${ }^{1} \mathrm{H}$ NMR, ${ }^{13} \mathrm{C}$ NMR, 2D NMR, and HRESITOFMS. Compound $\mathbf{1}$ was obtained as a yellow amorphous powder. IR data exhibited the presence of hydroxyl and carbonyl functional groups at 3253 and $1651 \mathrm{~cm}^{-1}, \mathrm{C}-\mathrm{H}$ stretching at $2956 \mathrm{~cm}^{-1}, \mathrm{C}=\mathrm{C}$ olefin ring at $1361 \mathrm{~cm}^{-1}$, asymmetric $\mathrm{C}-\mathrm{O}-\mathrm{C}$ stretching at $1171 \mathrm{~cm}^{-1}$, and substituted benzene at $828 \mathrm{~cm}^{-1}$. The ${ }^{1} \mathrm{H}$ NMR spectrum (see Supplementary Data) of $\mathbf{1}$ showed four aromatic hydrogen signals containing six protons (Table 1). Two protons at $7.84 \mathrm{ppm}\left(2 \mathrm{H}, \mathrm{dd}, J=8.7,2.8 \mathrm{~Hz}, \mathrm{H}-2^{\prime}\right.$ and H-6') and two protons at $7.01 \mathrm{ppm}\left(2 \mathrm{H}, \mathrm{dd}, J=8.7,2.8 \mathrm{~Hz}, \mathrm{H}-3\right.$ 'and $\left.\mathrm{H}-5^{\prime}\right)$ assigned symmetric pattern with substitution at 1 and 4 positions. ${ }^{1} \mathrm{H}-{ }^{1} \mathrm{H}$ COSY correlation showed two set of ortho-coupled aromatic protons at $7.84 \mathrm{ppm}\left(\mathrm{H}-2^{\prime} / \mathrm{H}-6^{\prime}\right)$ and $7.01 \mathrm{ppm}\left(\mathrm{H}-3^{\prime} / \mathrm{H}-5^{\prime}\right)$ with coupling constant as $J=8.7 \mathrm{~Hz}$. Furthermore, the proton at H-2' had meta-coupled with H-6', and H-3' with $\mathrm{H}-5^{\prime}(J=2.8 \mathrm{~Hz})$ of $\mathrm{B}$ ring of the flavone skeleton. A remaining two aromatic proton signals at $6.45 \mathrm{ppm}(1 \mathrm{H}, \mathrm{d}, J=2.3 \mathrm{~Hz})$ and $6.25 \mathrm{ppm}(1 \mathrm{H}, \mathrm{d}, J$ $=1.8 \mathrm{~Hz}$ ) were assigned at H-8 and H-6 positions. Accordingly, this compound was predicted to have trihydroxyl substitutions at C-5 (162.3 ppm), C-7 (164.3 ppm), and C-4' (157.7 ppm) in flavone skeleton. The ${ }^{13} \mathrm{C}$ NMR spectrum indicated 19 carbon signals. The correlation between proton and carbon in HMQC showed six methines aromatic at H-6 (6.25 ppm)/C-6 (98.8 ppm), H-8 (6.45 ppm)/C-8 (93.8 ppm), H-2' or H-6' (7.84 ppm)/C-2' and or C-6' (130.9 ppm), H-3' or H-5' (7.01 ppm)/C-3' and or C-5' (115.5 ppm). According to HMQC correlation, the remaining of annomeric proton located at $5.52 \mathrm{ppm}(1 \mathrm{H}, \mathrm{d}, J=1.4 \mathrm{~Hz})$, four oxygenated methines at $4.20 \mathrm{ppm}\left(1 \mathrm{H}, \mathrm{d}, J=1.4 \mathrm{~Hz}, \mathrm{H}-2^{\prime \prime}\right), 3.70$ ppm $\left(1 \mathrm{H}, \mathrm{dd}, J=3.7,8.7 \mathrm{~Hz}, \mathrm{H}-3^{\prime \prime}\right), 3.33 \mathrm{ppm}\left(2 \mathrm{H}, \mathrm{m}, \mathrm{H}-4^{\prime \prime}\right.$ and $\left.\mathrm{H}-5^{\prime \prime}\right)$, and one methyl at $0.90 \mathrm{ppm}\left(3 \mathrm{H}, \mathrm{d}, J=5.9 \mathrm{~Hz}, \mathrm{Me}-6^{\prime \prime}\right)$ indicated the occurrence of rhamnosyl unit in this compound. $\mathrm{HMBC}$ correlation of the annomeric proton at $5.52 \mathrm{ppm}$ with the annomeric carbon at $134.9 \mathrm{ppm}$ confirmed that sugar moiety was bound to the C-3 hydroxyl group. The HRESITOFMS data showed the molecular formula was established as $\mathrm{C}_{21} \mathrm{H}_{20} \mathrm{O}_{10}$ for the peak at $m / z 455.0944[\mathrm{M}+\mathrm{Na}]^{+}$(calcd. for $\mathrm{C}_{21} \mathrm{H}_{20} \mathrm{O}_{10} \mathrm{Na}$, 455.0954; error 2.2 $\mathrm{ppm})$. Compared the spectral data of the isolated compound with literature, we confirmed this isolated compound $\mathbf{1}$ as kaempferol-3$O$-rhamnoside (afzelin) (Suedee et al., 2013).

Compound $\mathbf{2}$ was obtained as a yellow amorphous powder. On the TLC, the spot of compound $\mathbf{2}$ was active under UV lamp 254 and $365 \mathrm{~nm}$ and came out yellow after spraying with $10 \%$ $\mathrm{CeSO}_{4}$, which was characteristic of flavone compound. The IR data of compound $\mathbf{2}$ indicated to bear the similar functional groups as similar as to compound 1, which were the vibrations of hydroxyl

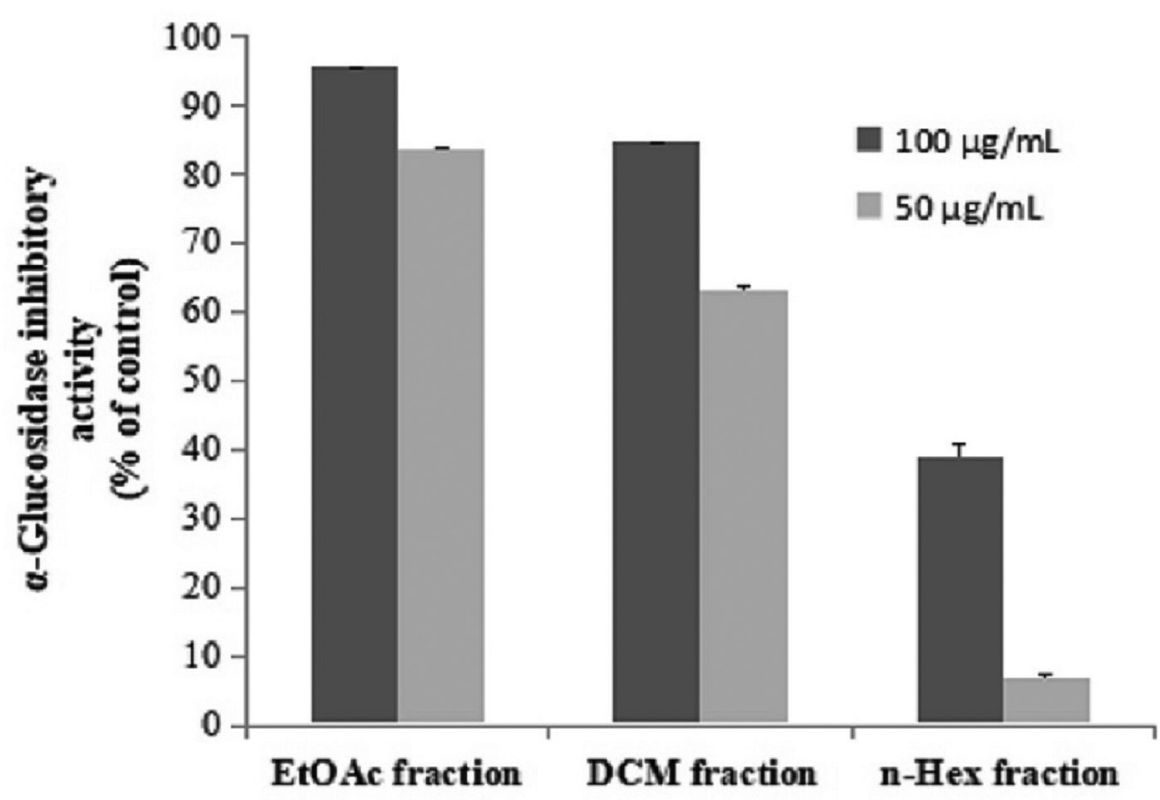

Figure 1. $\alpha$-Glucosidase inhibitory activity of Pometia pinnata leaves fractions (mean \pm SEM; $\mathrm{n}=5)$. 
group, $\mathrm{C}-\mathrm{H}$ stretching, carbonyl functional group, $\mathrm{C}=\mathrm{C}$ olefin ring, asymmetric C-O-C stretching, and substituted benzene at 3198 , $3002,1652,1354,1195$, and $808 \mathrm{~cm}-1$, respectively. The ${ }^{1} \mathrm{H}$ and ${ }^{13} \mathrm{C}$ NMR spectra of the compound $\mathbf{2}$ were also similar to the spectra of compound 1 . The ${ }^{1} \mathrm{H}$ NMR spectrum showed five aromatic proton signals at $7.33 \mathrm{ppm}\left(1 \mathrm{H}, \mathrm{d}, J=1.9 \mathrm{~Hz}, \mathrm{H}-2^{\prime}\right), 7.30(1 \mathrm{H}, \mathrm{dd}, J=8.2$, $\left.2.3 \mathrm{~Hz}, \mathrm{H}-6^{\prime}\right), 6.91\left(1 \mathrm{H}, \mathrm{d}, J=8.2 \mathrm{~Hz}, \mathrm{H}-5^{\prime}\right), 6.36(1 \mathrm{H}, \mathrm{d}, J=1.8$ $\mathrm{Hz}, \mathrm{H}-8), 6.20(1 \mathrm{H}, \mathrm{d}, J=1.8 \mathrm{~Hz}, \mathrm{H}-6)$. One set of meta-coupled aromatic protons appeared at $7.33 \mathrm{ppm}(\mathrm{d}, J=1.9 \mathrm{~Hz})$ and 7.30 ppm (dd, $J=2.3 \mathrm{~Hz}$ ), in other than proton at $7.30 \mathrm{ppm}$ (dd) also had ortho coupling with proton at $6.91 \mathrm{ppm}(\mathrm{d})$ with coupling constant of $J=8.2 \mathrm{~Hz}$. We confirmed the presence of three substitutions in $\mathrm{B}$ ring. Remaining two meta-coupled aromatic protons at 6.25 and $6.36 \mathrm{ppm}(J=1.8 \mathrm{~Hz})$ indicated dihydroxyl substitutions in A ring of flavone skeleton. The ${ }^{13} \mathrm{C}$ NMR spectrum showed 21 signals, containing 6 rhamnosyl carbon signals $(102.2,70.8,70.7,71.9,70.6$, and16.3 ppm) in Table 1. The molecular formula was established as $\mathrm{C}_{21} \mathrm{H}_{20} \mathrm{O}_{11}$ for the peak at $\mathrm{m} / \mathrm{z} 471.0886[\mathrm{M}+\mathrm{Na}]^{+}$(calcd. for $\mathrm{C}_{21} \mathrm{H}_{20} \mathrm{O}_{11} \mathrm{Na}$; error: $3.7 \mathrm{ppm}$ ) from HRESITOFMS. Comparing the spectral data of the isolated compound with related literature, we confirmed this isolated compound $\mathbf{2}$ as quercetin-3-O-rhamnoside (quercitrin) (Gopi et al., 2016).

\section{UPLC-ESI-TOFMS analysis}

The EtOAc fraction and isolated kaempferol-3-Orhamnoside (1) and quercetin-3-O-rhamnoside (2) were analyzed by UPLC-ESI-TOFMS. The chromatogram of the EtOAc fraction revealed two major peaks at retention time 34.16 and 41.23 min (Fig. 2A). Figure 2B shows the peak of kaempferol-3-Orhamnoside (1) which was detected at the retention time of 41.05 min, while the peak of quercetin-3-O-rhamnoside (2) revealed at the retention time $34.13 \mathrm{~min}$ (Fig 2C). Furthermore, a minor peak at retention time $28.92 \mathrm{~min}$ from EtOAc fraction of this plant also appeared (Fig 2A). Compared with the previously isolated compound, quercetin-3-O-glucoside (isoquercetin), appeared at retention time 28.54 min (Fig 2D). The minor peak at retention time $28.92 \mathrm{~min}$ in EtOAc fraction of $P$. pinnata leaves was confirmed to be quercetin-3-O-glucoside (Nishina et al., 2017).

\section{$\alpha$-Glucosidase inhibitory activity of isolated compounds}

In this study, two flavonol compounds kaempferol3-O-rhamnoside (1) and quercetin-3-O-rhamnoside (2) were isolated. The authors are interested in the structure-activity relationship of kaempferol derivatives and quercetin derivatives for $\alpha$-glucosidase inhibitory activity. Four kaempferol derivatives and four quercetin derivatives were chosen, which include eight derivatives, including kaempferol (7) and quercetin (8) and their derivatives, bearing sugar moiety into the $\mathrm{C}-3$ position, such as kaempferol-3-O-glucoside (3), quercetin-3- $O$-glucoside (4), kaempferol-3-O-glucosyl-( $1 \rightarrow 4)$-rhamnoside $(5)$, and quercetin3-O-glucosyl-( $1 \rightarrow 4)$-rhamnoside $(6)$ for this assay (Fig. 3).

The $\alpha$-glucosidase inhibitory activities all of the compounds (1-8) were evaluated according to the previous method with slight modification (Dewi et al., 2015). The \% inhibitions of compounds 1-8 are summarized in Table 2. The results showed that quercetin $\mathbf{8}$ had the strongest $\alpha$-glucosidase inhibitory activity among all the tested eight compounds (1-8). The \% inhibition of compounds 1 and 2 at final concentration $50 \mu \mathrm{M}$ were $45.06 \% \pm$ 0.22 and $34.83 \% \pm 0.59$ against $\alpha$-glucosidase, respectively, which were lower than that of kaempferol (7) and quercetin (8) with percent inhibition $82.93 \% \pm 0.37$ and $80.10 \% \pm 0.76$, respectively. We confirmed that the introduction of sugar moiety at the $\mathrm{C}-3$ position in the flavonol structure reduced $\alpha$-glucosidase inhibitory activity and that the hydroxyl group at the C-3 position was an essential requirement for the activity. Similar results have been reported, the hydroxyl group at the $\mathrm{C}-3$ and $\mathrm{C}-5$ positions on the $\mathrm{A}$ and $\mathrm{C}$ rings of
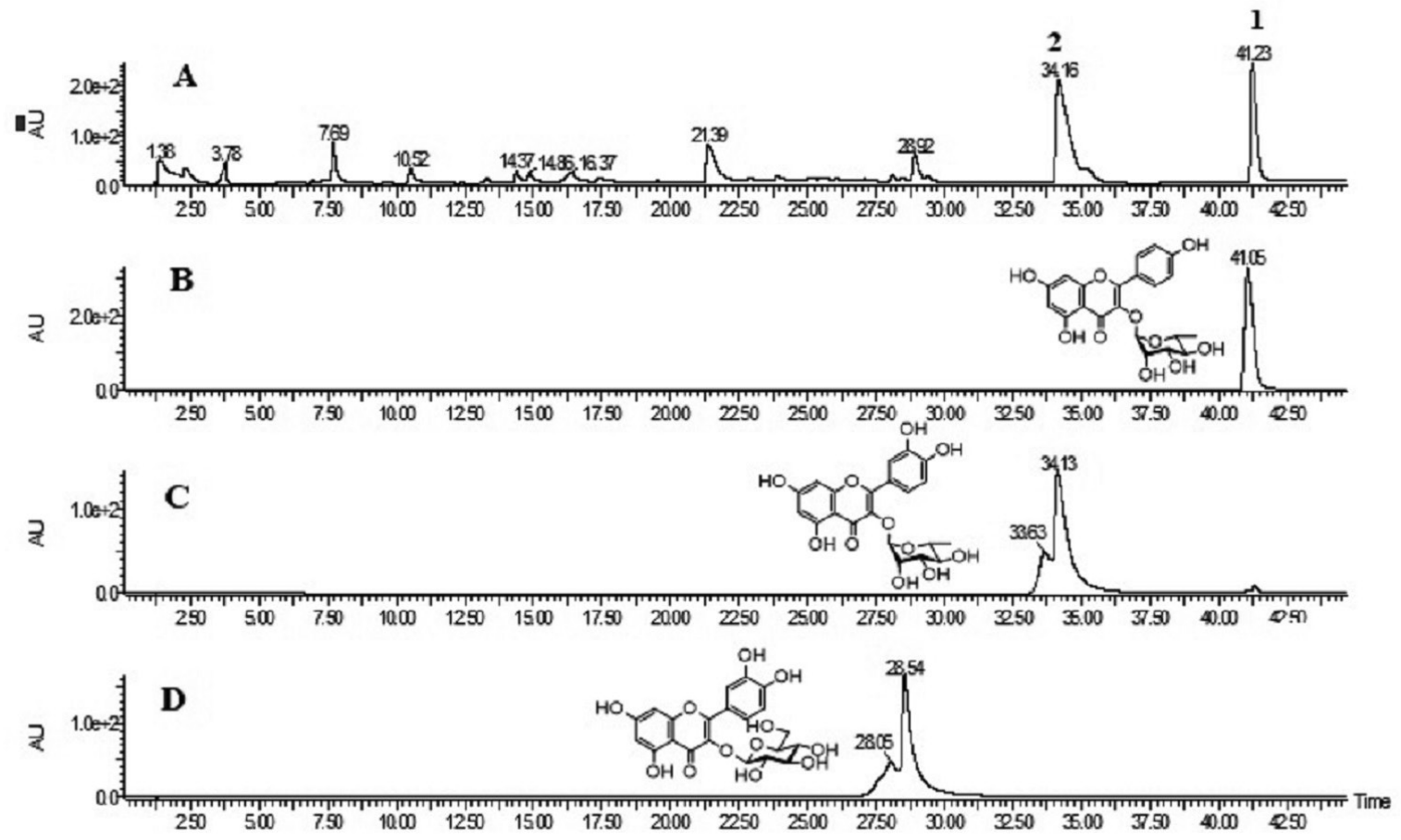

Figure 2. UPLC-ESI-TOFMS analyses of (A) EtOAc fraction of P. pinnata leaves, (B) Kaempferol-3-O-rhamnoside, (C) Quercetin-3-Orhamnoside, and (D) Quercetin-3-O-glucoside. 
Table 1. ${ }^{1} \mathrm{H}$ and ${ }^{13} \mathrm{C}$ NMR data of isolated compounds.

\begin{tabular}{|c|c|c|c|c|}
\hline \multirow{2}{*}{ Position } & \multicolumn{2}{|r|}{ Compound (1) ${ }^{\mathrm{a}}$} & \multicolumn{2}{|r|}{ Compound (2) ${ }^{\mathrm{b}}$} \\
\hline & $\delta \mathrm{C}$ & $\delta \mathrm{H}$ (mult., J (Hz)) & $\delta \mathrm{C}$ & $\delta \mathrm{H}$ (mult., J (Hz)) \\
\hline 2 & 157.1 & - & 157.2 & - \\
\hline 3 & 134.9 & - & 134.9 & - \\
\hline 4 & 178.4 & - & 178.3 & - \\
\hline 5 & 162.3 & - & 161.9 & - \\
\hline 6 & 98.8 & $6.25(1 \mathrm{H}, \mathrm{d}, \mathrm{J}=1.8)$ & 98.4 & $6.25(1 \mathrm{H}, \mathrm{d}, \mathrm{J}=1.8)$ \\
\hline 7 & 164.3 & - & 164.6 & - \\
\hline 8 & 93.6 & $6.45(1 \mathrm{H}, \mathrm{d}, \mathrm{J}=2.3)$ & 93.4 & $6.36(1 \mathrm{H}, \mathrm{d}, \mathrm{J}=1.8)$ \\
\hline 9 & 160.1 & - & 158.0 & - \\
\hline 10 & 104.9 & - & 104.5 & - \\
\hline $1^{\prime}$ & 121.6 & - & 121.6 & - \\
\hline $2^{\prime}$ & 130.9 & $7.84(1 \mathrm{H}, \mathrm{dd}, \mathrm{J}=8.7,2.8)$ & 115.0 & $7.33(1 \mathrm{H}, \mathrm{d}, \mathrm{J}=1.8)$ \\
\hline $3^{\prime}$ & 115.5 & $7.01(1 \mathrm{H}, \mathrm{dd}, \mathrm{J}=8.7,2.8)$ & 145.1 & - \\
\hline $4^{\prime}$ & 157.7 & - & 148.5 & - \\
\hline $5^{\prime}$ & 115.5 & $7.01(1 \mathrm{H}, \mathrm{dd}, \mathrm{J}=8.7,2.8)$ & 115.6 & $6.91(1 \mathrm{H}, \mathrm{d}, \mathrm{J}=8.3)$ \\
\hline $6^{\prime}$ & 130.9 & $7.84(1 \mathrm{H}, \mathrm{dd}, \mathrm{J}=8.7,2.8)$ & 121.5 & $7.30(1 \mathrm{H}, \mathrm{dd}, \mathrm{J}=8.3,2.3)$ \\
\hline $1^{\prime \prime}$ & 101.9 & $5.52(1 \mathrm{H}, \mathrm{d}, \mathrm{J}=1.4)$ & 102.2 & $5.30(1 \mathrm{H}, \mathrm{d}, \mathrm{J}=1.4)$ \\
\hline $2^{\prime \prime}$ & 71.0 & $4.20(1 \mathrm{H}, \mathrm{d}, \mathrm{J}=1.4)$ & 70.8 & $4.20(1 \mathrm{H}, \mathrm{d}, \mathrm{J}=1.4)$ \\
\hline $3^{\prime \prime}$ & 70.7 & $3.70(1 \mathrm{H}, \mathrm{dd}, \mathrm{J}=3.7,8.7)$ & 70.7 & $3.70(1 \mathrm{H}, \mathrm{dd}, \mathrm{J}=3.7,9.1)$ \\
\hline $4^{\prime \prime}$ & 72.0 & $3.33(2 \mathrm{H}, \mathrm{m})$ & 71.9 & $3.34(1 \mathrm{H}, \mathrm{dd}, \mathrm{J}=6.0,9.6)$ \\
\hline $5^{\prime \prime}$ & 70.6 & $3.33(2 \mathrm{H}, \mathrm{m})$ & 70.6 & $3.43(1 \mathrm{H}, \mathrm{dd}, \mathrm{J}=6.0,9.6)$ \\
\hline $6^{\prime \prime}$ & 17.0 & $0.90(3 \mathrm{H}, \mathrm{d}, \mathrm{J}=6.0)$ & 16.3 & $0.90(3 \mathrm{H}, \mathrm{d}, \mathrm{J}=6.0)$ \\
\hline
\end{tabular}

${ }^{a}$ Measured at $400 \mathrm{MHz}$ for ${ }^{1} \mathrm{H}$ and $100 \mathrm{MHz}$ for ${ }^{13} \mathrm{C}$ in $\left(\mathrm{CD}_{3}\right)_{2} \mathrm{CO}$.

${ }^{b}$ Measured at $400 \mathrm{MHz}$ for ${ }^{1} \mathrm{H}$ and $100 \mathrm{MHz}$ for ${ }^{13} \mathrm{C}$ in $\mathrm{CD}_{3} \mathrm{OD}$.<smiles>O=c1c(OC2OC3C(O)C(O)OC3(O)C2O)c(-c2ccc(O)cc2)oc2cc(O)cc(O)c12</smiles>

(1)<smiles>CC1OC(Oc2c(-c3ccc(O)c(O)c3)oc3cc(O)cc(O)c3c2=O)C(O)C(O)C1O</smiles>

(2)<smiles>O=C(O)C(O)C(=O)Oc1c(-c2ccc(O)cc2)oc2cc(O)cc(O)c2c1=O</smiles>

(3)

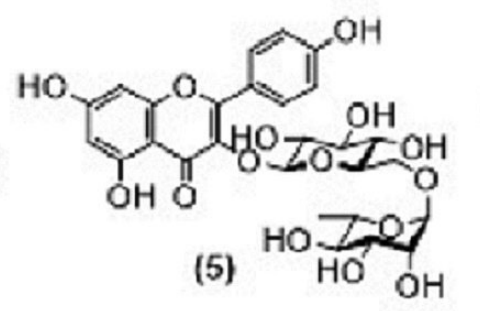<smiles>O=c1c(O)c(-c2ccc(O)cc2)oc2cc(O)cc(O)c12</smiles>

(7)

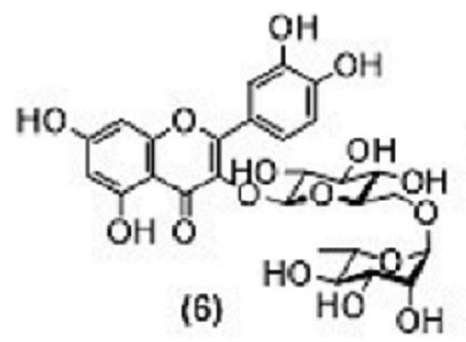<smiles>O=c1c(O)c(-c2ccc(O)c(O)c2)oc2cc(O)cc(O)c12</smiles>

(8)

Figure 3. Chemical structures of flavonols and their derivatives compounds: Kaempferol-3-O-rhamnoside (afzelin) (1), Quercetin-3-O-rhamnoside (quercitrin) (2), Kaempferol-3-O-glucoside (astragalin) (3), Quercetin-3-O-glucoside (isoquercetin), (4), Kaempferol-3-O-glucosyl-(1 $\rightarrow 4)$-rhamnoside (nicotiflorin) (5), Quercetin-3-O-glucosyl-(1 $\rightarrow$ 4)-rhamnoside (rutin) (6), Kaempferol (7), and Quercetin (8).

flavones enhancing the $\alpha$-glucosidase inhibitory activity (Tadera et al., 2006). Compounds $\mathbf{1}, \mathbf{3}$, and $\mathbf{5}$ possessed the same aglycone as kaempferol. Compound $\mathbf{1}$ had a stronger inhibitory activity against $\alpha$-glucosidase than that against of compounds 3 (percent inhibition $=37.18 \% \pm 0.62)$ and $5(\% \mathrm{I}=26.38 \% \pm 0.63)$. Quercetin-3-Orhamnoside (2) had a stronger inhibitory effect among quercetin derivatives $(\mathbf{2}, \mathbf{4}$, and $\mathbf{6})$. The flavonol rhamnosides ( $\mathbf{1}$ and $\mathbf{2})$ were stronger than flavonol glucosides ( $\mathbf{3}$ and $\mathbf{4}$ ) and flavonol rutinosides (5 and 6). According to the literature data, kaempferol and quercetin showed stronger $\alpha$-glucosidase inhibitory activity than that positive control (acarbose) (Abbasi et al., 2014; Proenca et al., 2017; Sheng et al., 2017). Kaempferol and quercetin from C. asiatica showed 
Table 2. $\alpha$-Glucosidase inhibitory activity of flavonols and their derivatives at the final concentration of $50 \mu \mathrm{M}$.

\begin{tabular}{|c|c|}
\hline Compounds & $\begin{array}{l}\alpha \text {-Glucosidase inhibitory activity } \\
\text { ( } \% \text { of control) }\end{array}$ \\
\hline Kaempferol-3-O-rhamnoside (afzelin) (1) & $45.06 \pm 0.22$ \\
\hline Quercetin-3-O-rhamnoside (quercitrin) (2) & $34.83 \pm 0.59$ \\
\hline Kaempferol-3-O-glucoside (astragalin) (3) & $37.18 \pm 0.62$ \\
\hline Quercetin-3-O-glucoside (isoquercetin) (4) & $31.26 \pm 0.46$ \\
\hline $\begin{array}{l}\text { Kaempferol-3-O-glucosyl-(1 } \rightarrow 4 \text { )- } \\
\text { rhamnoside (nicotiflorin) (5) }\end{array}$ & $26.38 \pm 0.63$ \\
\hline $\begin{array}{l}\text { Quercetin-3-O- glucosyl-( }(1 \rightarrow 4) \text { - } \\
\text { rhamnoside (rutin) (6) }\end{array}$ & $26.67 \pm 0.88$ \\
\hline Kaempferol (7) & $80.10 \pm 0.76$ \\
\hline Quercetin (8) & $82.93 \pm 0.37$ \\
\hline
\end{tabular}

Mean \pm SEM, $n=5$.

strong $\alpha$-glucosidase inhibitory with $\mathrm{IC}_{50} 16 \sim 22 \mu \mathrm{g} / \mathrm{ml}$ (Dewi and Faiza, 2015). Both compounds also were reported to inhibit the rat small intestinal $\alpha$-glucosidase (Tadera et al., 2006). On the other hand, the inhibitory activity of flavonoid glycosides is usually lower than that the aglycones (Sarian et al., 2017). The mechanism of kaempferol and quercetin as an antidiabetic treatment showed that they were competitive inhibitors for inhibitory $\alpha$-glucosidase (Proenca et al., 2017; Sheng et al., 2017).

\section{CONCLUSION}

The EtOAc fraction from $P$. pinnata leaves contained the highest $\alpha$-glucosidase inhibitory activity. This result was obtained after the isolation of two flavonol rhamnosides, such as kaempferol3-O-rhamnoside (1) and quercetin-3-O-rhamnoside (2), from the EtOAc fraction of $P$. pinnata leaves. Based on the structureactivity relationship among tested compounds (1-2 from $P$. pinnata leaves, 3-5 from Eleutherococcus sieboldianus leaves, and 6-8 from commercial available), the quercetin (8) showed the highest $\alpha$-glucosidase inhibitory activity among eight flavonol derivatives. Compound $\mathbf{1}$ had stronger inhibitory activity than that of compound 2. In the flavonol structure, the occurrence of sugar moiety at C-3 position reduced the $\alpha$-glucosidase inhibitory activity. Among flavonol derivatives, the rhamnoside moiety bound to flavonol structure (1 and 2) was stronger than flavonol glucoside ( $\mathbf{3}$ and $\mathbf{4})$ and flavonol rutinoside ( $\mathbf{5}$ and $\mathbf{6})$ against $\alpha$-glucosidase.

\section{ACKNOWLEDGMENTS}

This study was financially funded by The Ministry of Research and Technology of Republic of Indonesia through "Master Program of Education Leading to Doctoral Degree for Excellent Graduate (PMDSU)" scholarship (Grant number: 059/SP2H/LT/ DRPM/IV/2017). The authors would also like to thank to Mr. Daiki Kaneko and Mr. Eito Horiyama for their fruitful assistance.

\section{CONFLICT OF INTEREST}

The authors declare that there are no conflicts of interest.

\section{REFERENCES}

Abbasi MA, Ghulam H, Aziz-ur-Rahman, Viqar UA. Flavonoids from Rhynchosia pseudo-cajan as suitable $\alpha$-glucosidase inhibitors and free radical scavengers. Int Res J Pharm, 2014; 5:636-41.

Dewi RT, Faiza M. Antioxidant and $\alpha$-Glucosidase inhibitory compounds of Centella asiatica. Procedia Chem, 2015; 17:147-52.
Dewi RT, Tachibana S, Fajriah S, Hanaf M. $\alpha$-Glucosidase inhibitor compounds from Aspergillus terreus $\mathrm{RCC} 1$ and their antioxidant activity. Med Chem Res, 2015; 24:737-43.

Elya B, Handayani R, Sauriasari R, Azizahwati, Hasyyati US, Permana IT, Permatasari YI. Antidiabetic activity and phytochemical screening of extracts from Indonesian plants by inhibition of $\alpha$-amylase, $\alpha$-glucosidase and dipeptidyl peptidase IV. Pak J Biol Sci, 2015; 18:279-84.

Gopi K, Anbarasu K, Renu K, Jayanthi S, Vishwanath BS, Jayaraman G. Quercetin-3-O-rhamnoside from Euphorbia hirta protects against snake Venom induced toxicity. Biochim Biophys Acta, 2016; 1860:1528-40.

Jayasinghe ULB, Wannigama GP, Fujimoto Y. Chemistry and bioactivity of saponins from some Sri Lankan plants. In: Oleszek W, Marston A (eds.). Saponins in food, Feedstuffs and Medicinal Plants, Kluwer Academic, The Netherlands, 2000; 45:113-9.

Kawamura F, Shaharuddin NA, Sulaiman O, Hashim R, Ohara S. Evaluation antioxidant activity, antifungal activity and total phenols of 11 selected commercial Malaysian timber species. Jpn Agr Res Quart, 2010; $44: 319-24$.

Lense $\mathrm{O}$. The wild plants used as traditional medicines by indigenous people of Manokwari, West Papua. Biodiversitas, 2012; 13:98106.

Nishina A, Itagaki M, Suzuki Y, Koketsu M, Ninomiya M, Sato D, Suzuki T, Hayakawa S, Kuroda M, Kimura H. Effects of flavonoids and triterpene analogues from leaves of Eleutherococcus sieboldianus (Makino) Koidz. 'Himeukogi' in 3T3-L1 preadipocytes. Molecules, 2017; 22:671-9.

Pardede A, Koketsu M. Antioxidant and antileukemic activity of chemical compounds from bark of Mangifera casturi. Comp Clin Pathol, 2017; 26:499-504.

Pereira DF, Cazarolli LH, Lavado C, Mengatto V, Figueiredo MSRB, Guedes A, Pizzolatti MG, Silva FRMB. Effects of flavonoids on $\alpha$-glucosidase activity: potential targets for glucose Homeostasis. Nutrition, 2011;27:1161-7.

Proenca C, Freitas M, Ribeiro D, Oliveira EFT, Sousa JLC, Tome SM, Ramos MJ, Silva AMS, Fernandes PA, Fernandes E. $\alpha$-Glucosidase inhibition by flavonoids: an in vitro and in silico structure-activity relationship study. J Enzyme Inhib Med Chem, 2017; 32:1216-28.

Sarian MN, Ahmed QU, So'ad SZM, Alhassan MA, Murugesu S, Perumal V, Mohamad SNAS, Khatib A, Latip J. Antioxidant and antidiabetic effects of flavonoids: a structure-activity relationship based study. BioMed Res Int, 2017; 2017:1-14.

Sauriasari R, Azizah N, Basah K. Tyrosinase inhibition, 2,2-diphenyl-1-picrylhydrazyl radical scavenging activity, and phytochemical screening of fractions and ethanol extract from leaves and stem bark of matoa (Pometia pinnata). Asian J Pharm Clin Res, 2017; 10:85-9.

Sheng Z, Ai B, Zheng L, Zheng X, Xu Z, Shen Y, Jin Z. Inhibitory activities of kaempferol, galangin, carnosic acid and polydatin against glycation and $\alpha$-amylase and $\alpha$-glucosidase enzymes. Int J Food Sci Technol, 2017; 53:755-66.

Suedee A, Tewtrakul S, Panichayupakaranant P. Anti-HIV-1 integrase compound from Pometia pinnata leaves. Pharm Biol, 2013; 51:1256-61.

Tadera K, Minami Y, Takamatsu K, Matsuoka T. Inhibition of $\alpha$-glucosidase and $\alpha$-amylase by flavonoids. J Nutr Sci Vitaminol, 2006; $52: 149-53$.

How to cite this article:

Utari F, Itam A, Syafrizayanti S, Putri WH, Ninomiya M, Koketsu M, Tanaka K, Efdi M. Isolation of flavonol rhamnosides from Pometia pinnata leaves and investigation of $\alpha$-glucosidase inhibitory activity of flavonol derivatives. $\mathrm{J}$ Appl Pharm Sci, 2019; 9(08):053-065. 


\section{SUPPLEMENTARY DATA}

\section{Compound 1}

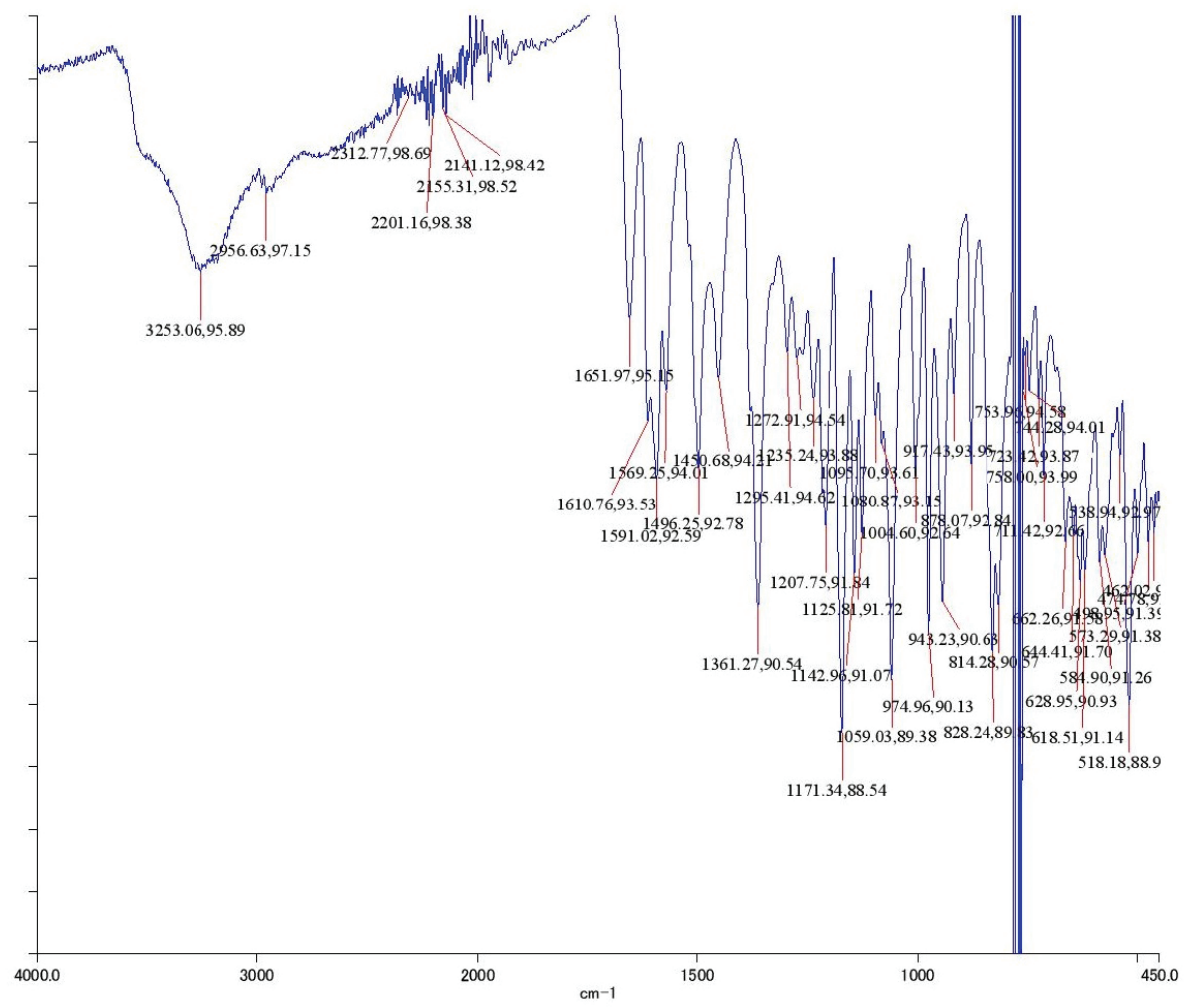

IR Spectrum of Compound 1

H-NMR Compound 1 (Utari)

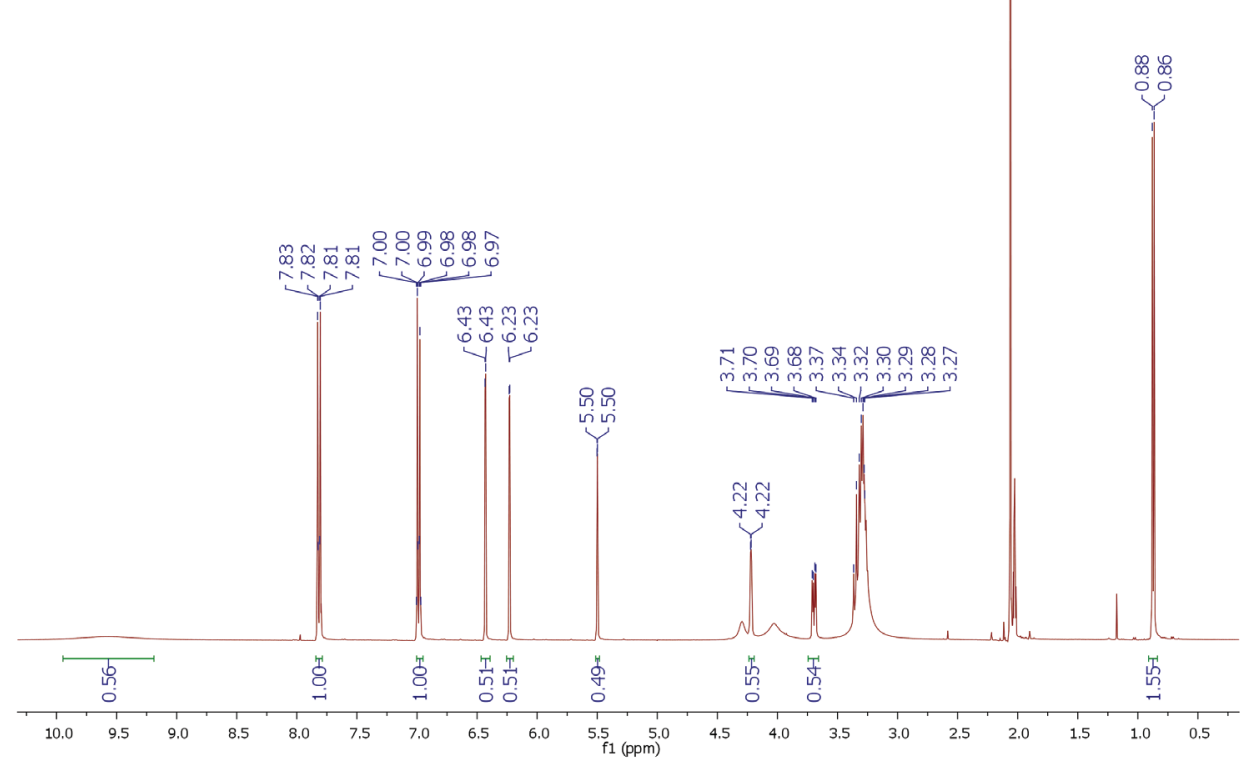

1H-NMR Spectrum of Compound 1 


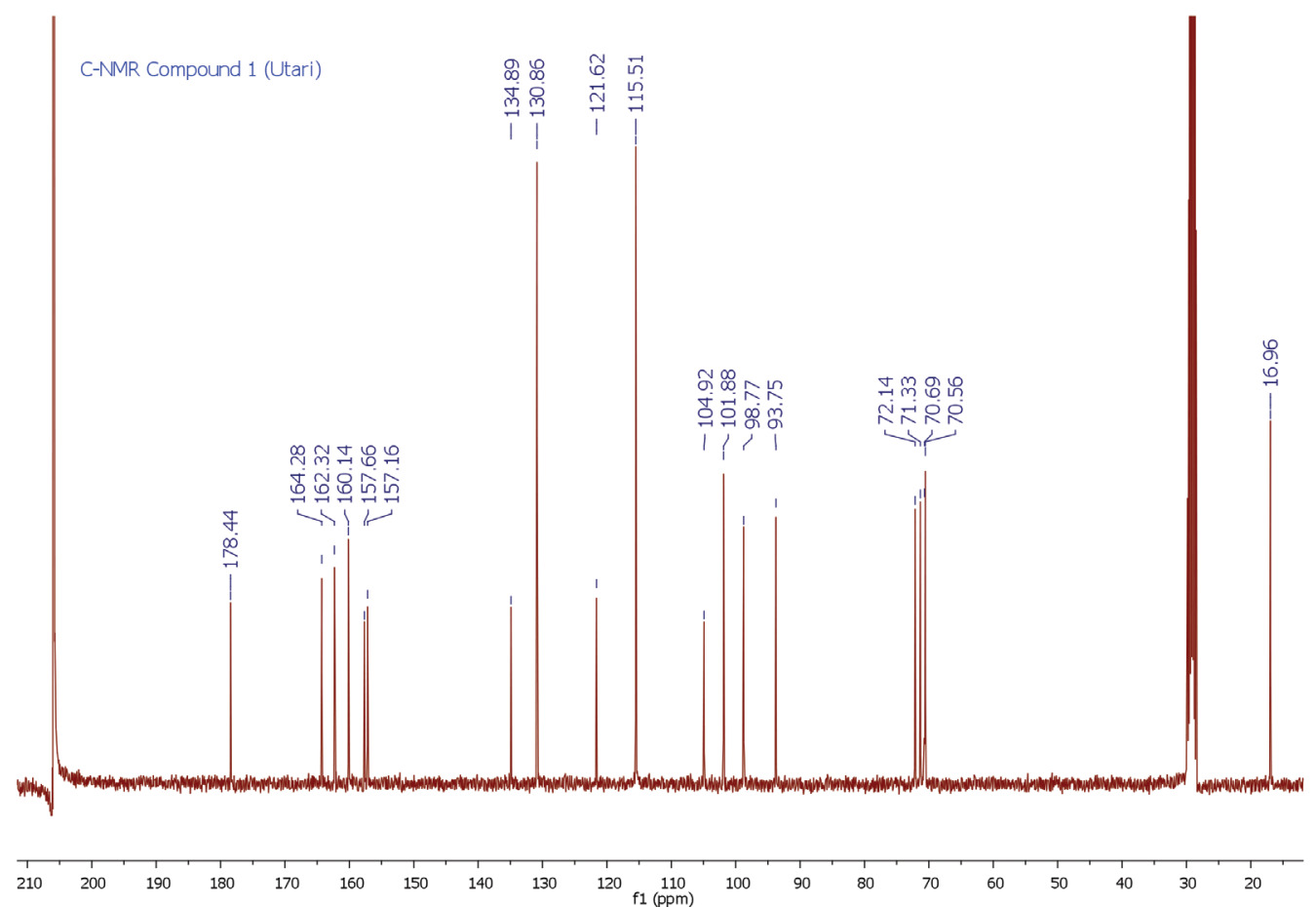

13C-NMR Spectrum of Compound 1

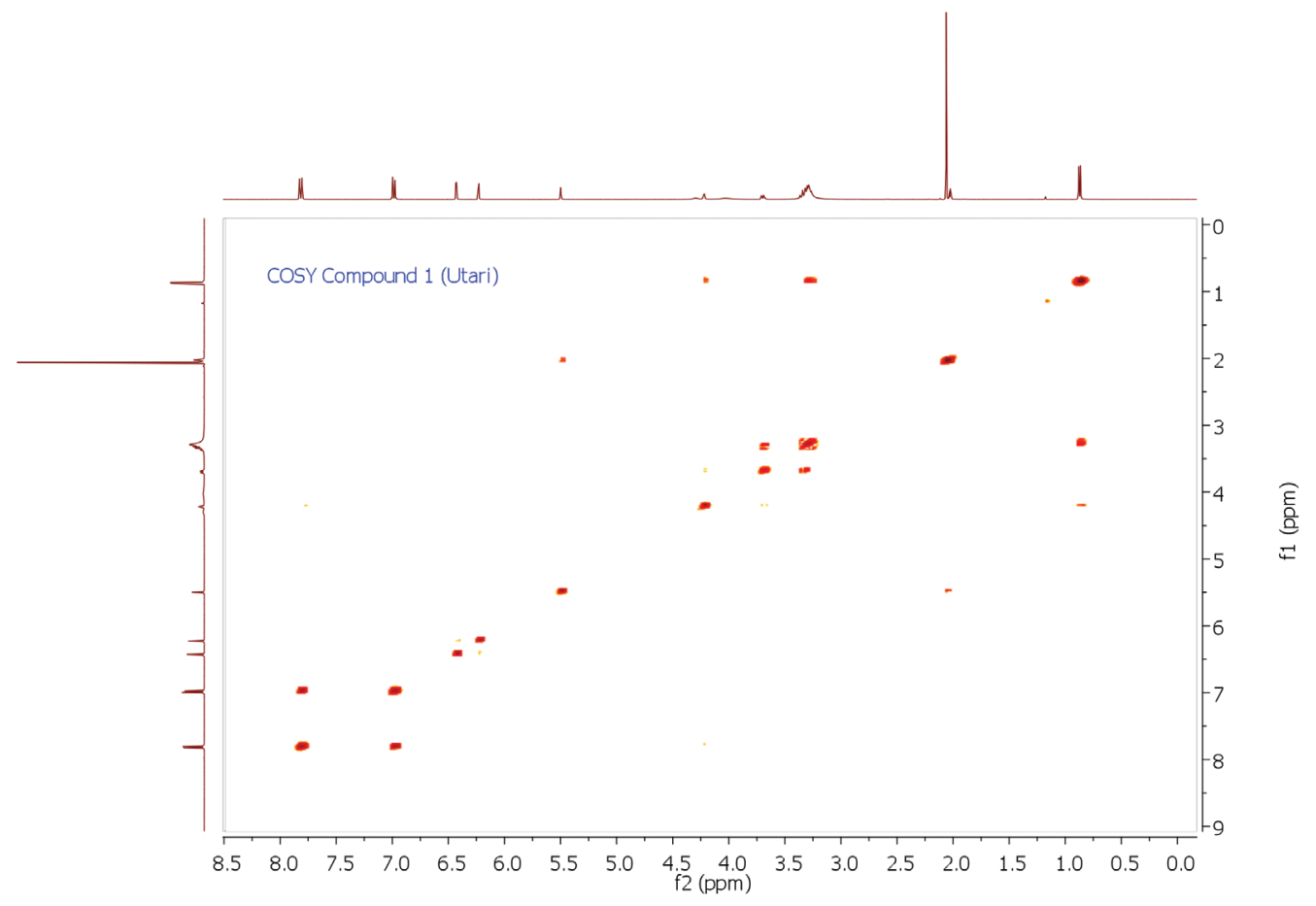

COSY Spectrum of Compound 1 


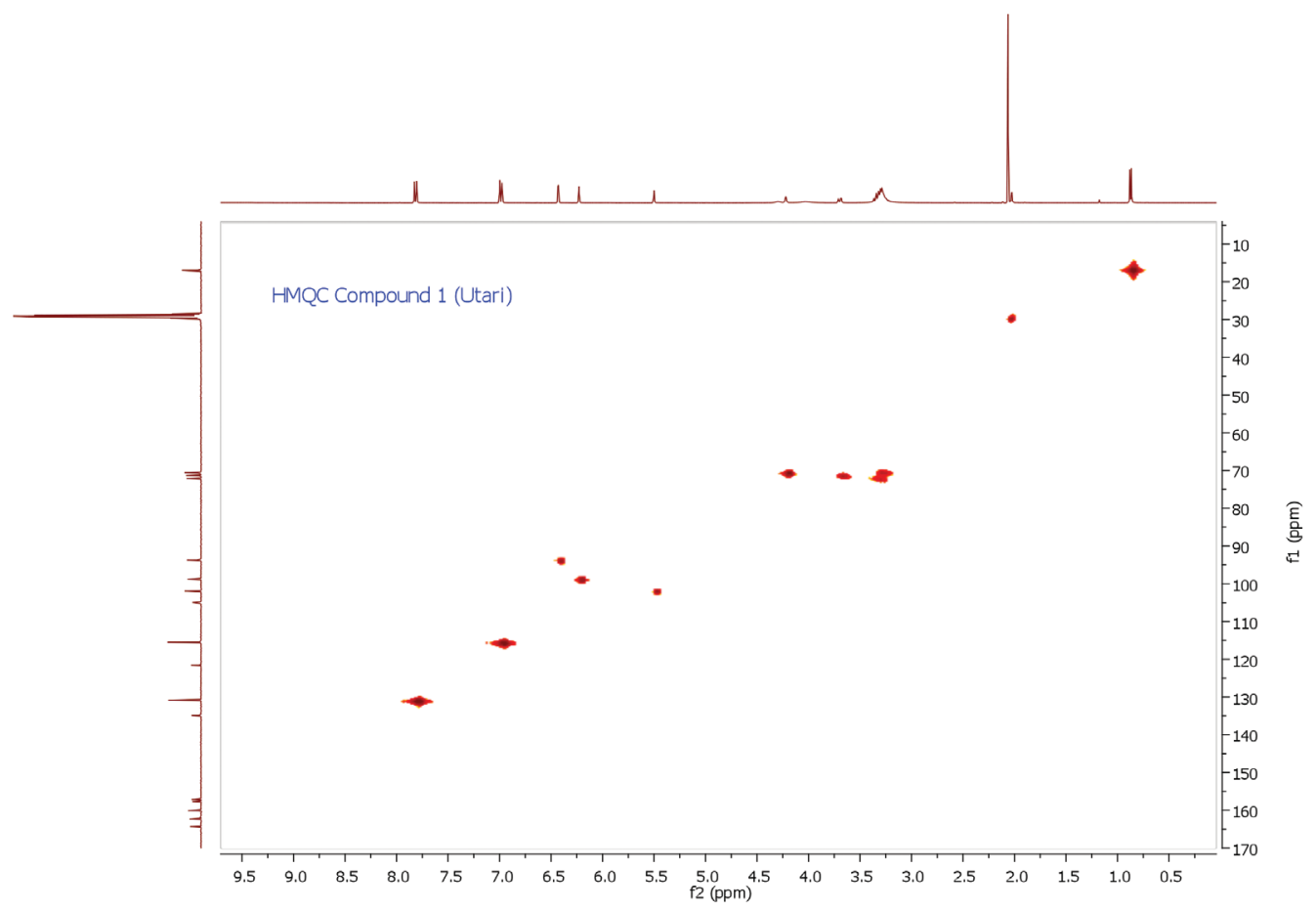

HMQC Spectrum of Compound 1

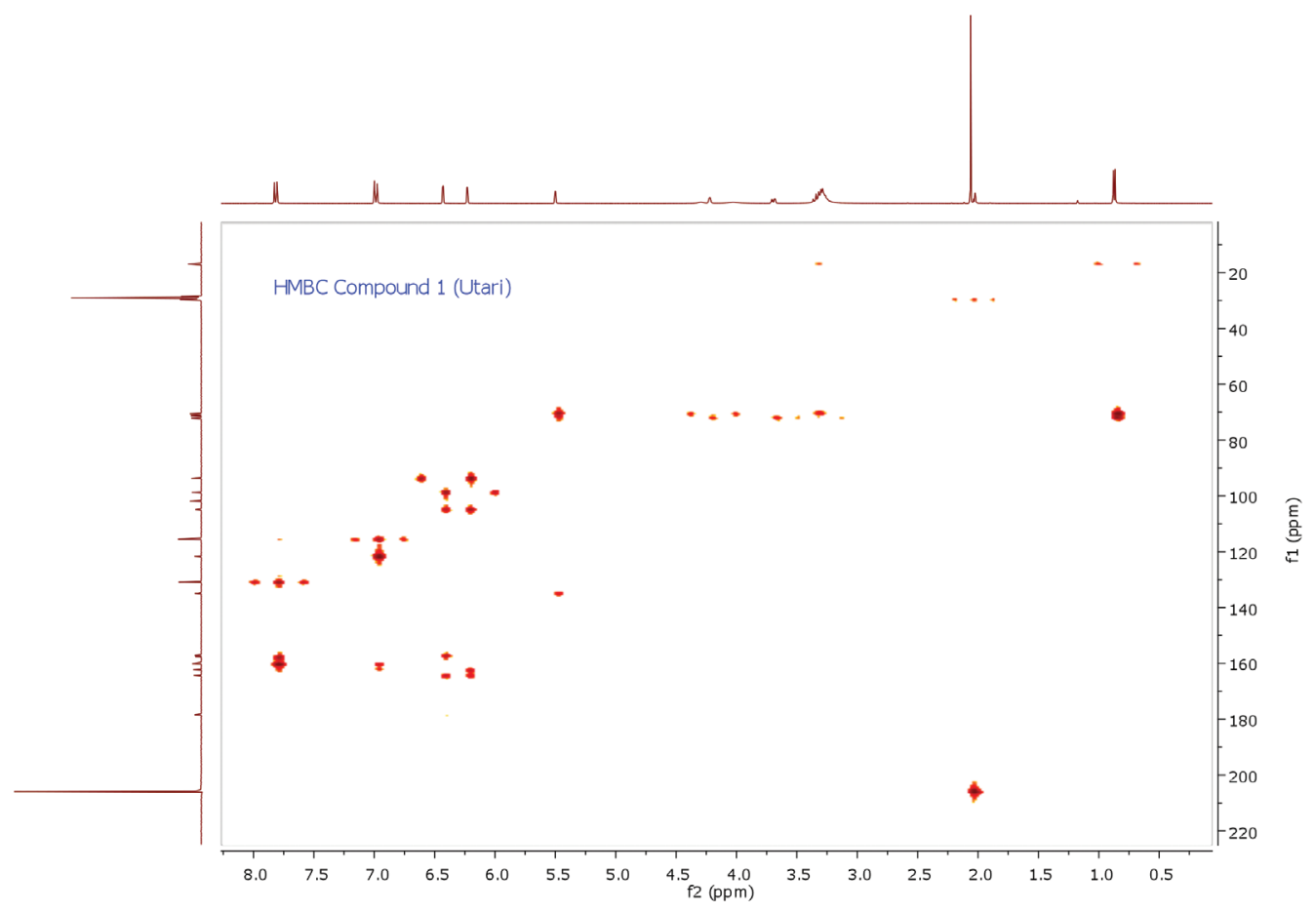

HMBC Spectrum of Compound 1 


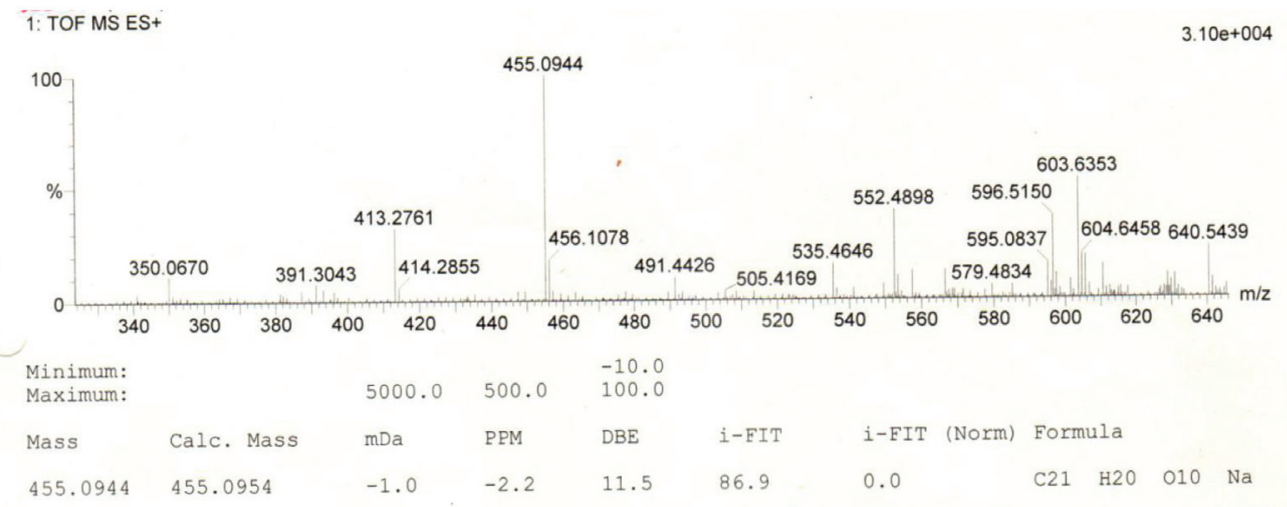

MS Spectrum of Compound 1

\section{Compound 2}

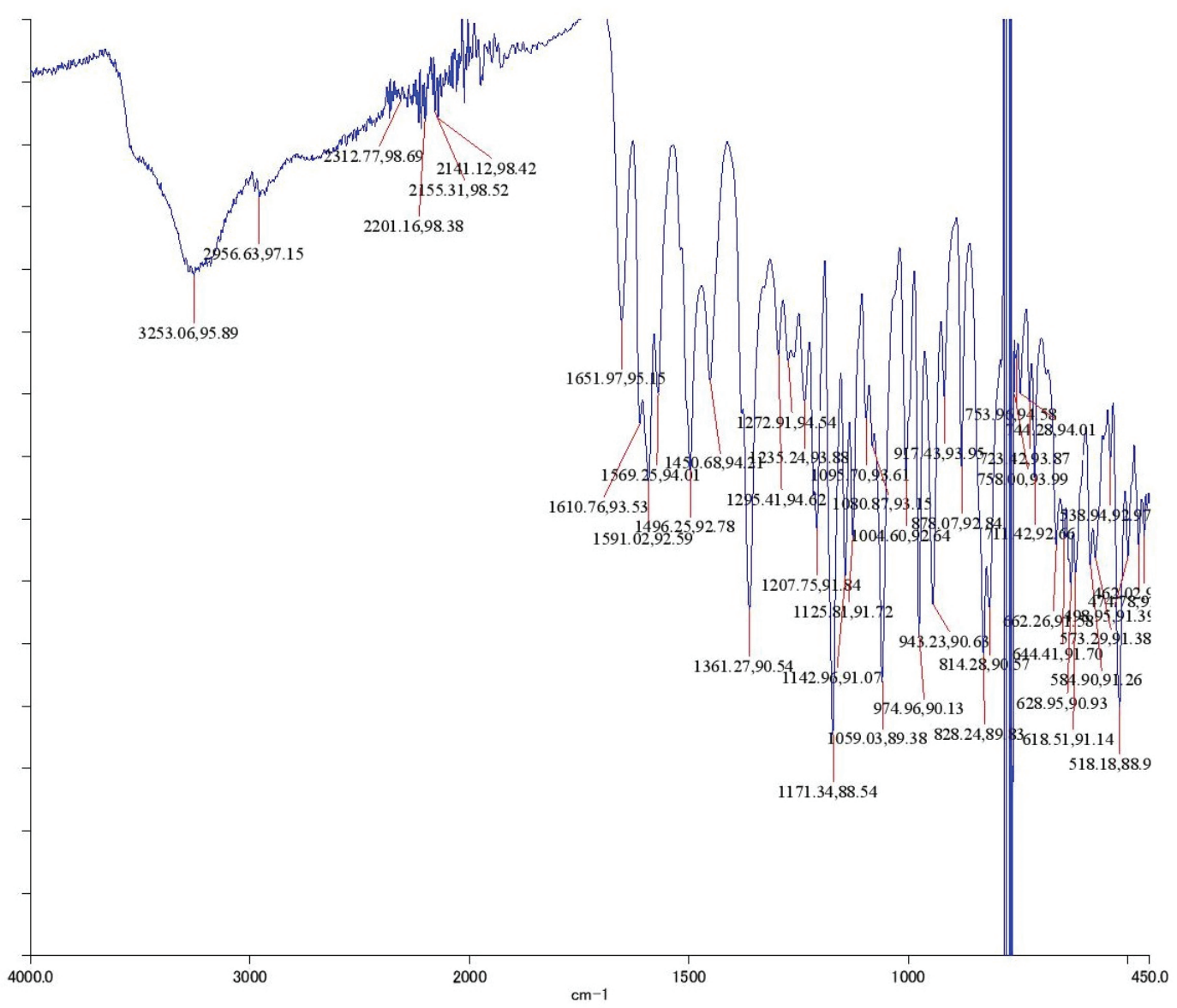

IR Spectrum of Compound 1 


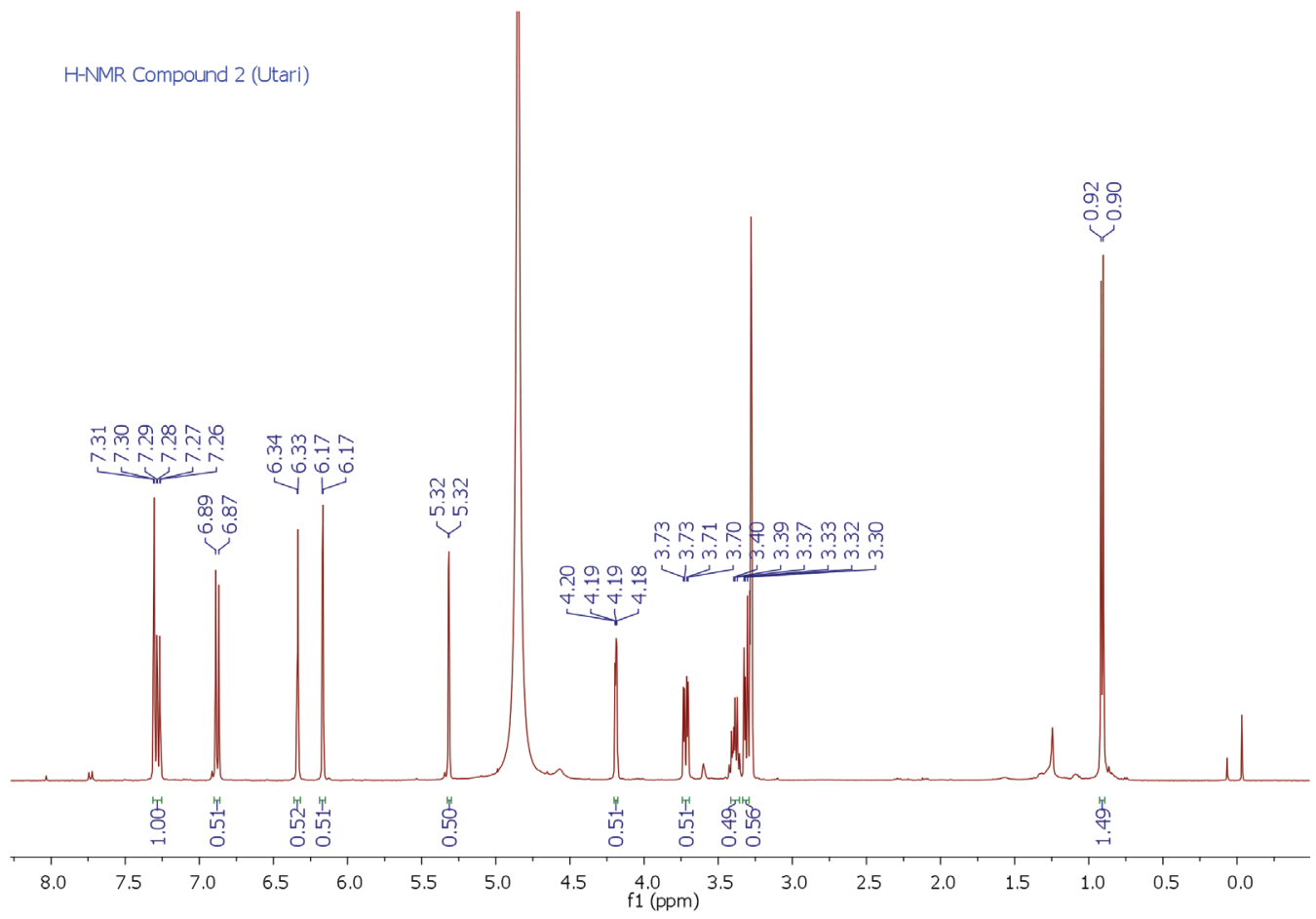

1H-NMR Spectrum of Compound 2

C-NMR Compound 2 (Utari)
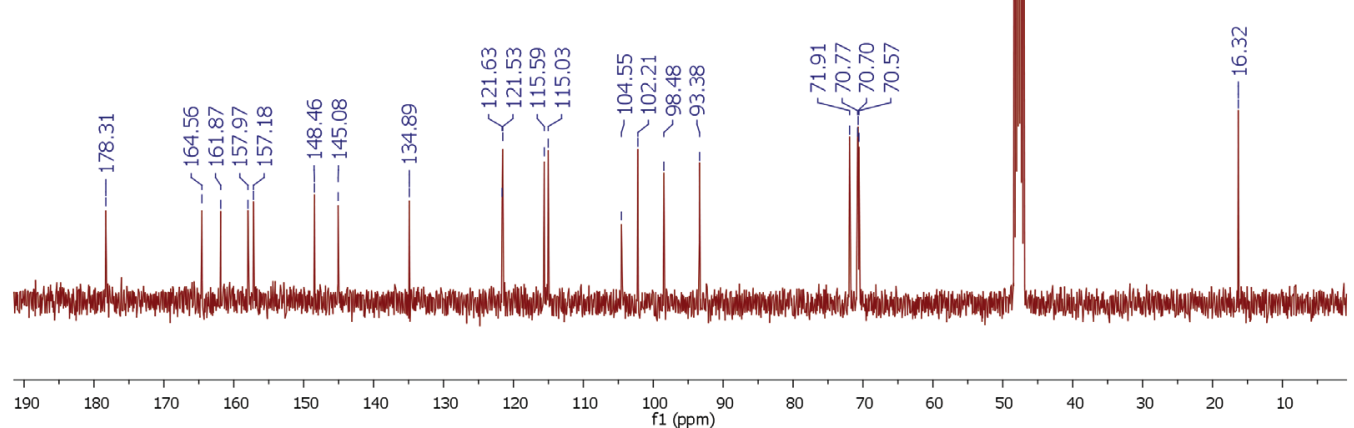

13C-NMR Spectrum of Compound 2 


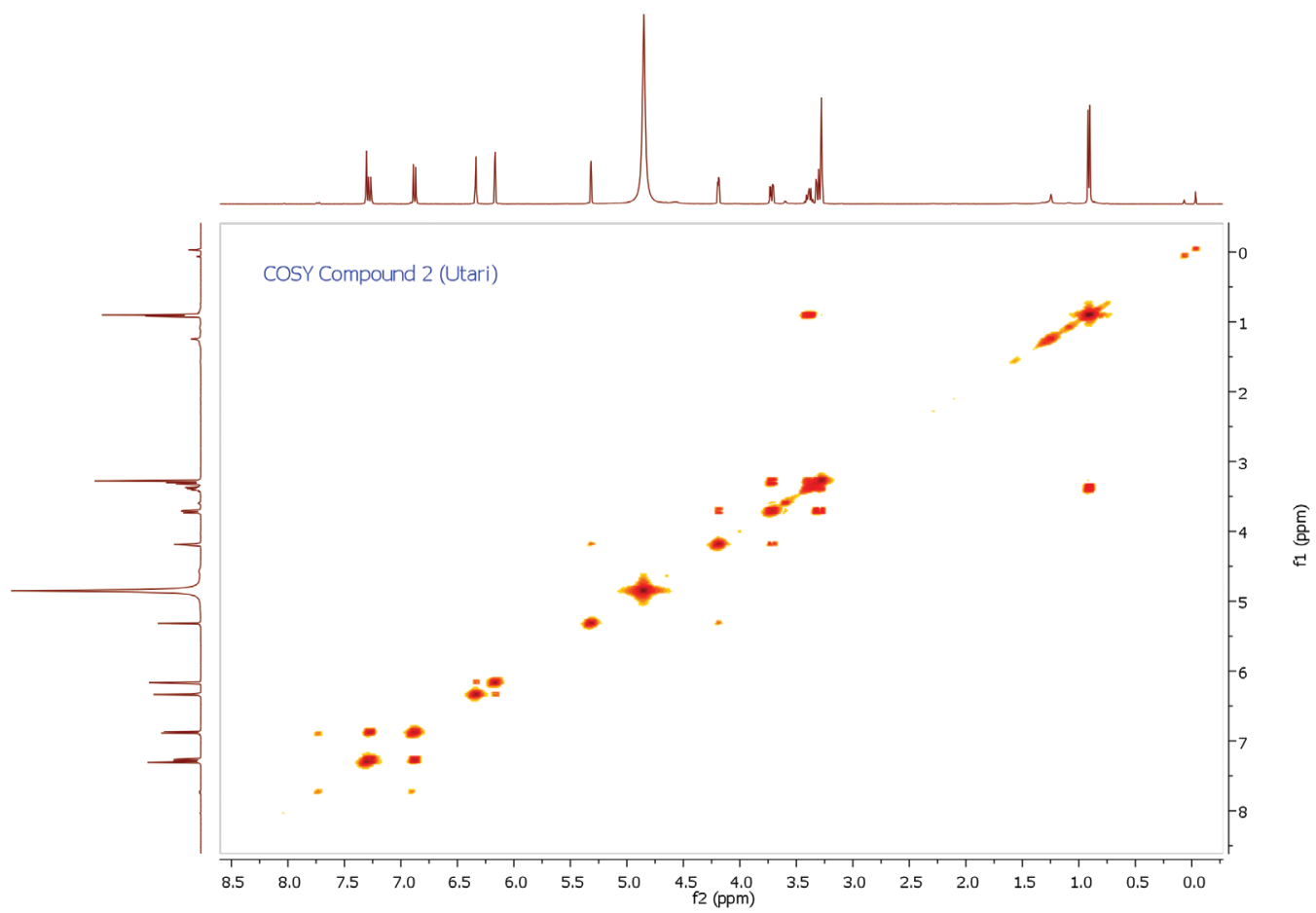

COSY Spectrum of Compound 2

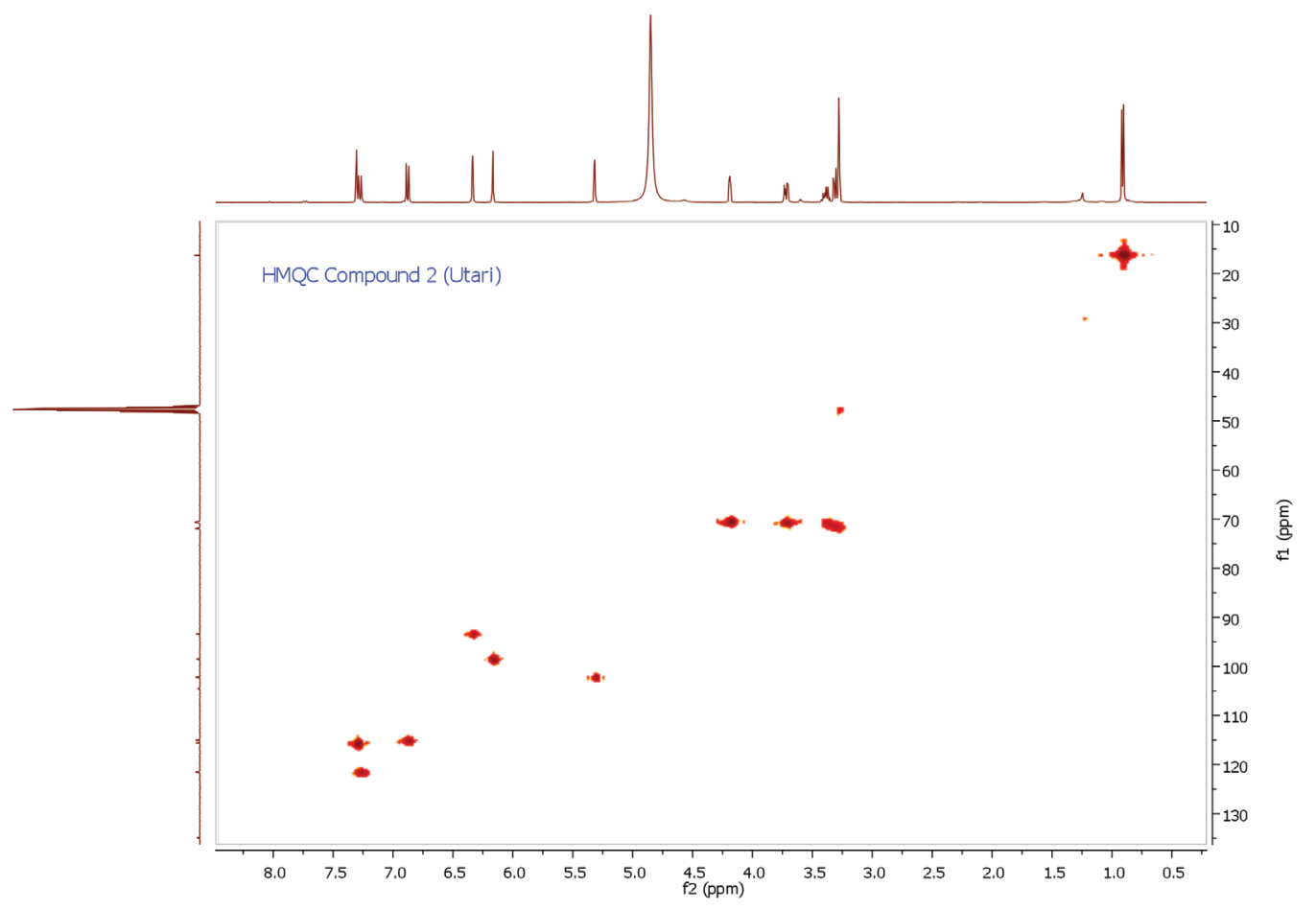

HMQC Spectrum of Compound 2 


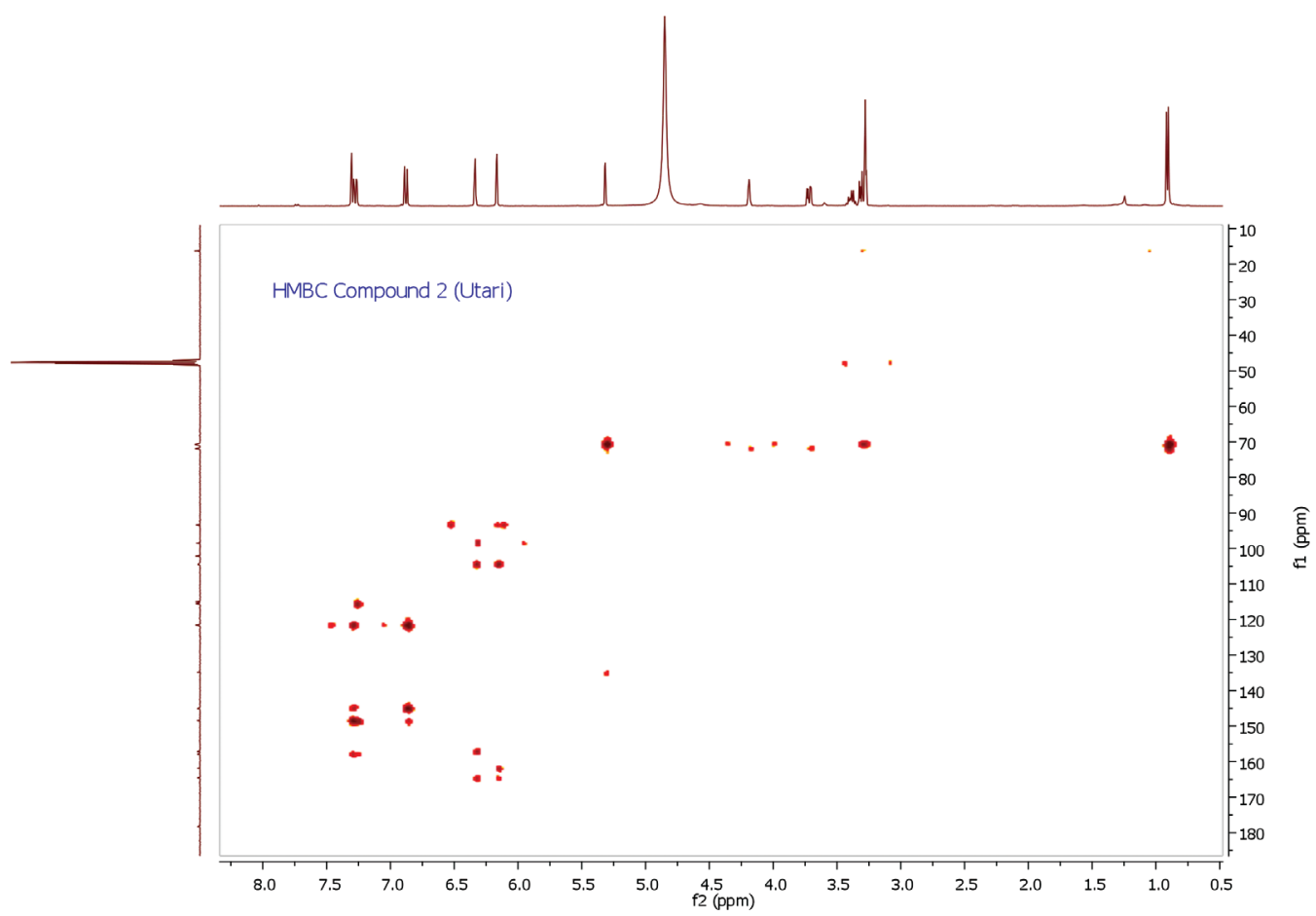

HMBC Spectrum of Compound 2

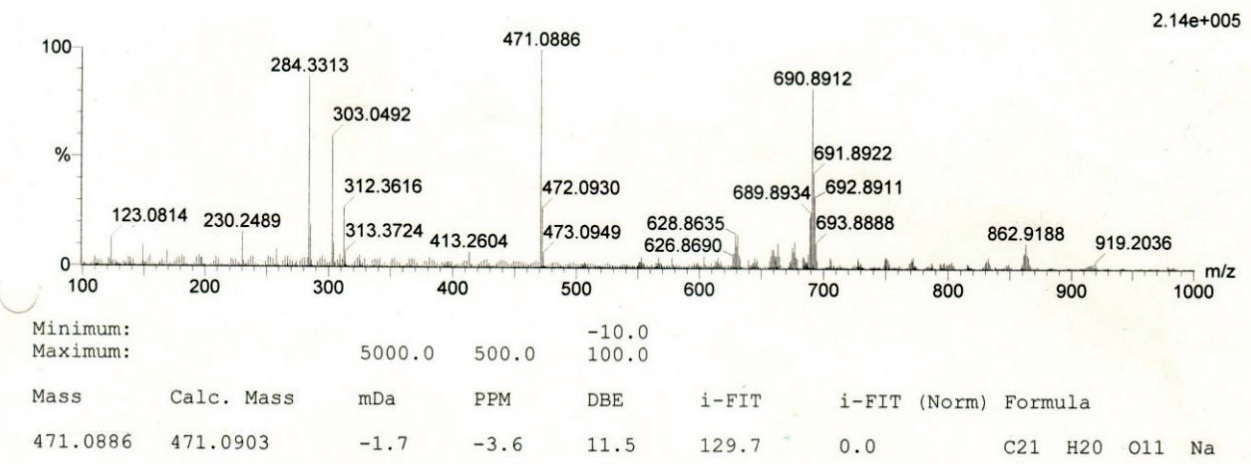

MS Spectrum of Compound 2 